\title{
ANALISIS PENERAPAN VALUE CREATION SELLING DALAM STRATEGI PEMASARAN PERUSAHAAN JASA LOGISTIK: STUDI KASUS DI PT XYZ
}

\author{
Darjat Sudrajat \\ Jurusan Manajemen, Fakultas Ekonomi dan Komunikasi, BINUS University \\ Jln. K.H. Syahdan No. 9, Palmerah, Jakarta Barat 11480 \\ sudrajatd@binus.ac.id
}

\begin{abstract}
A company is a market-oriented when the culture of value creation superior customer systematically and comprehensively implemented on company concerned. Value can be defined as the ratio of benefit to cost, where customers expect a rate of return equal or exceed the costs they incurred to obtain the products they bought. From the case studies conducted on PT XYZ, then, in getting the project tender delivery of goods geophysical equipment for the Brunei Loon project, it has been implemented value selling creation, which includes three main components, ie customer portraits, the proposed value, and benefits to customers or total value of ownership. Overall, the efficiency given value is about $20 \%$ compared to its closest competitor, the safety shipping and on time, as well as the positive benefits of the profit margin, cash flow, return on investment, brand equity, market share and customers.
\end{abstract}

Keywords: value creative selling, value account planning, total value of ownership, marketing strategy

\begin{abstract}
ABSTRAK
Suatu perusahaan berorientasi pasar ketika budaya penciptaan nilai pelanggan yang superior dijalankan secara sistematis dan menyeluruh pada perusahaan yang bersangkutan. Nilai dapat diartikan sebagai rasio manfaat terhadap biaya, di mana pelanggan mengharapkan tingkat pengembalian yang seimbang atau melebihi dari biaya yang mereka keluarkan untuk mendapatkan produk yang mereka beli. Dari studi kasus yang dilakukan pada PT XYZ, maka dalam mendapatkan tender proyek pengiriman barang-barang geophysical equipment untuk proyek Loon-Brunei telah diterapkan value creation selling, yang meliputi tiga komponen utama, yaitu potret pelanggan, usulan nilai, dan manfaat bagi pelanggan atau total value of ownership. Secara keseluruhan, nilai efisiensi yang diberikan adalah sekitar 20\% dibanding pesaing terdekat, pengiriman barang yang aman dan tepat waktu, serta manfaat yang positif terhadap profit margin, cash flow, return on investment, brand equity, dan market share pelanggan.
\end{abstract}

Kata kunci: value creative selling, value account planning, total value of ownership, marketing strategy 


\section{PENDAHULUAN}

Pemasaran adalah mengelola hubungan pelanggan yang menguntungkan dengan tujuan memberikan superior value kepada pelanggan baru dan menjaga sekaligus meningkatkan kepuasan pelanggan yang ada sekarang (Kotler, 2011). Pemasaran juga merupakan proses penciptaan nilai yang luar biasa kepada para pelanggan dan pemegang saham (Fisk, 2011). Suatu perusahaan adalah berorientasi pasar ketika budaya penciptaan nilai pelanggan yang superior dijalankan secara sistematis dan menyeluruh pada perusahaan yang bersangkutan. Oleh sebab itu, strategi pemasaran meliputi kegiatan analisis, pengembangan strategi, dan implementasi pengembangan suatu visi pasar yang menarik bagi perusahaan, memilih target pasar, menetapkan sasaran-sasaran, mengembangkan, mengimplementasikan, dan mengelola program positioning pemasaran yang didesain untuk memenuhi nilai yang dibutuhkan oleh pelanggan dalam setiap target pasar (Craven, 2009).

Nilai dapat diartikan sebagai rasio manfaat terhadap biaya, maksudnya adalah bahwa pelanggan mengharapkan tingkat pengembalian yang seimbang atau melebihi dari biaya-biaya yang mereka keluarkan untuk mendapatkan produk yang mereka beli. Oleh sebab itu, penjualan yang menambah nilai merupakan serangkaian perbaikan-perbaikan yang kreatif dalam proses penjualan yang meningkatkan pengalaman pelanggan. Tenaga penjual (sales force) dapat menciptakan nilai dengan mengembangkan suatu hubungan kualitas, mengenali kebutuhan pelanggan, dan kemudian merancang serta mempresentasikan solusi produk yang paling memungkinkan (Manning, 2007). Dalam proses penjualan konsultatif, nilai juga menjadi fokus utama, dimana usaha penjualan diarahkan pada penciptaan nilai baru dan menyediakan manfaat tambahan diluar produk itu sendiri (Johnston, 2011).

Dalam proses penjualan, tidak ada orang yang selalu sukses, namun bila kita selalu gagal melakukan penjualan meskipun produk dan layanan kita sangat baik, sudah waktunya kita berhenti sejenak untuk merenung. Kita harus memikirkan kembali apa yang akan kita coba raih dan bagaimana cara untuk meraihnya, mungkin kita sudah harus menciptakan cara baru dalam melakukan penjualan (Charan, 2007). Proses penjualan tradisional sudah banyak mengalami perubahan, sehingga fungsi tenaga penjual berubah dari semula sebagai penerima pesanan menjadi duta, yang menggunakan keterampilan bergaul mereka untuk mencari tahu kebutuhan pelanggan dan dengan pengetahuan produk yang mereka miliki memperkenalkan produk serta jasa untuk memenuhi kebutuhan tersebut.

Pada banyak bidang usaha terdapat banyak pemasok dan setiap hari semakin banyak pemasok memasuki pasar. Semua pelanggan mempunyai akses terhadap harga dan spesifikasi dari pemasok dimanapun. Ketimpangan informasi kini sudah dikoreksi. Pada saat yang sama, pelanggan berada dalam tekanan berat untuk membawa nilai kepada klien dan pemegang saham. Mereka tetap terus memanfaatkan kekuatan transparansi dan kelebihan kapasitas untuk menekan harga, yang mengakibatkan terjadinya komoditisasi yang terkadang menghancurkan penjual. Pelanggan dapat mengadu satu pemasok dengan yang lain dalam perdagangan online yang dapat menekan harga sedemikian rendah sehingga penjual tak menghasilkan keuntungan.

Dalam kondisi seperti ini, hubungan yang sudah lama terjalin dan produk berkualitas saja tidaklah cukup. Penjual boleh jadi mempunyai strategi hebat, teknologi berbeda, siklus pengembangan produk yang lebih cepat, operasi yang efisien, dan teman baik di perusahaan, tetapi tetap tidak berhasil melakukan penjualan atau menjual dengan harga premium. Margin laba sering ditekan, penjual tidak dapat mempertahankan pelanggan, dan pertumbuhan produk andalan tidak berhasil. Tekanan pada pelanggan untuk berprestasi sebenarnya merupakan peluang besar bagi para pemasok yang dapat membantu. Pelanggan harus memenuhi harapan finansial mereka tetapi juga harus berhasil di pasar. Jadi, sementara menginginkan harga rendah, mereka juga ingin klien menyukai produk dan jasa mereka. Mereka ingin mengalahkan pesaing dan bertahan di depan. Mereka ingin mengembangkan 
bisnis dan meningkatkan penghasilan, serta mereka ingin uang tetap mengalir masuk. Singkatnya, mereka ingin bisnis berhasil dalam berbagai dimensi. Meskipun mungkin tidak berterus terang, mereka ingin pemasok membantu mereka meraih hal-hal tersebut sebagai mitra, bukan sebagai penjual pada saat itu saja.

Pelanggan ingin kita memahami seluk beluk bisnis mereka sehingga kita sebagai pemasok, dapat membantu mereka menjalankan bisnis dengan lebih baik. Itu adalah kata kuncinya, kita tidak akan dapat melakukanya dengan pendekatan penjualan tradisional. Sesungguhnya, fungsi penjualan yang sudah lama diabaikan sudah tidak selaras dengan peluang yang ada saat ini. Meski Tim Manajemen mencoba membangkitkanya dengan sistem insentif baru dan orang-orang baru tetap diperlukan lebih banyak perubahan radikal.

Inti dari pendekatan baru terhadap penjualan adalah fokus yang kuat pada kesejahteraan pelanggan. Hal itu bertolak belakang dengan apa yang dilakukan sebagian besar penjual dan organisasi penjualan. Seluruh orientasi psikologisnya digeser 180 derajat. Kita tidak lagi terlebih dahulu mengkur kesuksesan kita. Sebaliknya, kita mengukur kesuksesan dengan mengukur seberapa baik kinerja perusahaan pelanggan setelah mendapatkan bantuan kita. Kita tidak berfokus pada menjual sebuah produk atau jasa tertentu, kita berfokus pada bagaimana perusahaan dapat membantu keberhasilan pelanggan dalam segala hal yang penting bagi pelanggan tersebut. Dengan mendayagunakan berbagai sumber yang kita miliki untuk membantu pelanggan meraih cita-cita dan prioritas bisnis, kita memberikan nilai tambah. Kemampuan menciptakan nilai bagi pelanggan akan membedakan kita dalam pasar yang sesak, dan kita akan menerima pembayaran yang sepadan atas usaha kita ini, pembayaran yang setimpal dengan nilai yang pelanggan rasa telah mereka peroleh dan nilai sebenarnya yang kita berikan. Pendekatan ini dinamakan dengan Value Creation Selling atau VCS (Charan, 2008)

Penjualan penciptaan nilai berbeda sama sekali dengan cara sebagian besar perusahaan menjual saat ini, dalam hal: Pertama, waktu dan energi yang dicurahkan jauh lebih banyak untuk mempelajari bisnis pelanggan secara mendetil. Apa sasaran pelanggan? Langkah finansial apa yang paling mereka minati? Bagaimana mereka menciptakan nilai pasar dan faktor penting apa yang membedakan produk atau jasa mereka dari pesaing? Setelah itu maka dapat ditemukan cara untuk membantu pelanggan dalam jangka pendek, menengah, dan panjang. Peluang terbesar berada pada jangka menengah dan panjang, di mana perusahaan dan pelanggan dapat bekerja sama untuk mengubah sifat permainan dalam industri pelanggan berdasarkan nilai yang dapat diberikan.

Kedua, menggunakan kemampuan dan alat baru untuk memahami cara pelanggan menjalankan bisnis dan bagaimana cara membantu mereka memperbaki bisnis tersebut. Tugas penjualan tidak lagi hanya dilakukan oleh tenaga penjual, tetapi juga harus dibantu dari bagian lain. Orang dari berbagai departemen, termasuk departemen hukum, keuangan, riset dan pengembangan, pemasaran, dan manufaktur, menjadi akrab dengan pelanggan. Perlu mengumpulkan banyak infomasi tentang pelanggan, baik fakta maupun kesan, dalam database bermanfaat yang dibagi dan digunakan untuk menentukan pendekatan terbaik dalam membantu keberhasilan pelanggan. Hal ini mengharuskan adanya pengembangan jejaring sosial baru baik dalam perusahaan kita maupun antara perusahaan kita dan perusahaan pelanggan. Informasi harus mengalir dua arah, dan harus ada interaksi resmi serta tidak resmi di antara orang-orang yang menjalankan berbagai fungsi dalam perusahaan serta antara perusahaan dan pelanggan.

Ketiga, tidak cukup mengenal pelanggan, tetapi juga perlu mengenal pelanggan dari pelanggan. Tidak cukup sekadar memuaskan permintaan pelanggan. Kita juga harus tahu apa yang memotivasi pelanggan dari pelanggan. Agar dapat menyesuaikan solusi dengan pasar pelanggan, kita harus mengetahui siapa pelanggan mereka, apa yang mereka inginkan, apa masalah serta perilaku mereka, dan apa proses pembuatan keputusan yang mereka gunakan. Untuk membuat penawaran yang unik kepada pelanggan, perusahaan kita harus mampu menelusuri ke belakang, dari kebutuhan 
pelanggan akhir hingga kebutuhan pelanggan, termasuk rantai nilai pelanggan. Keempat, membutuhkan siklus waktu yang lebih lama dalam memproduksi pesanan dan menghasilkan pendapatan. Kita harus memiliki kesabaran, konsistensi, dan kegigihan untuk membangun rasa percaya yang tinggi dengan pelanggan. Hal ini sangat penting karena dalam hubungan baru ini, pertukaran informasi dua arah jauh lebih dalam apa yang kita andalkan di masa lalu. Namun, sekalinya berjalan, siklus waktu dapat berlangsung sangat cepat karena kita sudah membangun kepercayaan dan kredibilitas.

Akhirnya, adanya sistem penghargaan dan pemberian imbalan yang baru. Dalam pendekatan ini, keberhasilan mencapai target penjualan per kuartal bukan satu-satunya patokan untuk memberikan imbalan kepada tenaga penjual. Lebih jauh, anggota tim penjulan lain dari berbagai bagian fungsional juga harus dihargai dan diberi imbalan secara proporsional atas kontribusi mereka. Bila setelah mendapatkan pelatihan dan dukungan yang memadai para tenaga penjual atau eksekutif fungsional lain tidak mengadopsi pendekatan baru ini dengan antusiasme penuh, kita harus mengganti beberapa orang.

Penjualan penciptaan nilai menuntut adanya perubahan berarti pada bagian penjualan. Tenaga penjual tidak lagi bekerja sendiri, mereka menjadi pemimpin tim yang bertanggung jawab mengatur dan mengarahkan beberapa kelompok ahli dari beragam disiplin, seperti keuangan, hukum, serta manufaktur, dalam organisasi mereka sendiri. Fungsi pendukung perusahaan kita harus bekerja secara sungguh-sungguh dengan para pemimpin tenaga penjual, dengan menyesuaikan prioritas mereka dengan kebutuhan yang dipersiapkan pimpinan tenaga penjual. Ini adalah peran yang biasa dijalankan tenaga penjual, dan banyak di antara mereka pada mulanya akan merasa tidak yakin dengan kemampuan kepemimpinan mereka. Namun, sebagian besar tenaga penjual memiliki keluwesan dalam hubungan antar pribadi. Banyak diantara mereka akan berhasil mengkoordinasi upaya rekan dengan baik dan melakukannya dengan senang hati.

Tenaga penjual harus menguasai seperangkat pengetahuan dan alat analisis baru agar dihormati serta dituruti anggota Tim. Mereka harus mampu meneliti dan memahami bisnis pelanggan, termasuk segmen pasar pelanggan serta tren dalam industri pelanggan, dan yang paling penting adalah cara bisnis pelanggan sekarang serta di masa yang akan datang. Untuk memperoleh pengetahuan ini, tenaga penjual harus sering meminta rekan satu tim melibatkan diri dengan orang di perusahaan pelanggan. Para rekan satu Tim akan mengembangkan koneksi mereka sendiri dalam perusahaan pelanggan dan menyumbangkan wawasan mereka untuk membantu Tim mengembangkan visi tentang tren masa depan serta gagasan untuk membantu pelanggan.

Kemungkinan hal yang paling mematahkan semangat tenaga penjual adalah mereka harus menjadi ahli diagnosis. Dengan menggunakan pengetahuan mereka sendiri dan semua kemampuan lain yang dibutuhkan terkait urusan penjualan, tenaga penjual harus mengembangkan sebuah definisi yang sangat jelas dan spesifik menyangkut kebutuhan bisnis pelanggan. Mereka harus mendayagunakan kreativitas dan keahlian rekan mereka untuk membentuk beberapa penawaran alternatif guna memuaskan kebutuhan tersebut dan menguji alternatif ini lewat cara bekerja sama dengan orang di organisasi pelanggan, tetapi dibawah kepemimpinan tenaga penjual. Terakhir, tenaga penjual harus memperbaiki usulan nilai dan siap menunjukkan terutama kepada pembuat keputusan utama, bagaimana hal ini menguntungkan bagi bisnis pelanggan.

Penjualan Penciptaan Nilai tidak berakhir begitu penjualan terlaksana. Interaksi di antara banyak orang di organisasi pelanggan dan organisasi penjual penting dari membangun hubungan saling percaya yang diperlukan untuk mengembangkan usulan nilai di masa depan, termasuk beberapa usulan dengan jangka waktu lebih panjang. Tenaga penjual harus memastikan solusinya tidak saja memberikan hasil yang dijanjikan, tetapi juga bahwa dialog yang terus berlangsung dengan pelanggan memberikan harapan, bertenaga, dan ditujukan untuk menciptakan gagasan. 
Bila memikirkan betapa seringnya pekerjan penjualan berubah, kita akan menyadari bahwa ada hal penting yang terjadi, tenaga penjual yang mampu melaksanakan pendekatan ini berubah menjadi seorang General Manager yang bertanggungjawab atas pembuatan keputusan, analisis, kepemimpinan, dan laba/rugi yang merupakan bagian dari tugas ini. Perusahaan memperoleh sumber bakat manajemen umum yang sebelumnya tidak dimiliki, sementara para tenaga penjual mendapatkan jalur karier baru. Jajaran tenaga penjual kita yang lebih sukses dapat dengan mudah menapak ke jabatan lebih tinggi, terutama sebagai kepala pusat riset dan pengembangan atau unit bisnis, atau bahkan akhirnya menjadi CEO.

Penjualan Penciptaan Nilai berbicara tentang penciptaan kembali bagian muka perusahaan dengan hasrat akan perubahan yang mencerminkan taruhannya. Keberhasilan pelaksanaan VCS akan memberi manfaat signifikan bagi perusahaan, baik secara internal maupun dalam pasar yang kompetitif. Bila menjadi salah seorang yang pertama mengadopsi VCS dalam industri, maka kita akan mempunyai keuntungan daya saing yang signifikan. Tidak ada obat mujarab seketika. Seandainya ada, sebagian besar orang akan berhasil sejak dulu. Namun, para pemimpin yang ingin maju, yang mempunyai pembawaaan yang cocok untuk melaksanakan penjualan penciptaan nilai dan mempertahankannya, akan mampu membuat perusahaan berhasil secara konsisten. Pemasok yang menciptakan nilai sesungguhnya bagi pelanggan akan mengatasi persaingan dan memperoleh keuntungan lebih besar berkat strategi, inovasi besar, serta orang-orang berbakat mereka.

Kita harus menghadapi kenyataan bahwa proses penjualan sudah terpecah. Kini pelanggan memiliki lebih banyak pilihan dan berada di bawah tekanan untuk memberikan hasil. Namun, hanya sedikit perusahaan yang mengubah cara menjual mereka di hadapan realitas ini. Bila mereka tidak melakukannya, akan timbul rasa tidak nyaman yang berkepanjangan ketika hasil penjualan tidak mencapai target dan pemimpin senior terus-menerus gagal menghasilkan pertumbuhan produk andalan. Untuk memperbaiki proses penjualan yang rusak, kita harus tahu secara persis hal yang dihargai pelanggan, mengapa mereka memilih kita daripada pesaing dan mengapa mereka akan terus mengandalkan kita serta mempertahankan hubungan organisasi berdasarkan kepercayaan terhadap kita. Melakukan penjualan bukanlah sasaran, melainkan gejala komunikasi yang sukses. Ini sebuah gejala yang menunjukkan bahwa kita memahami pelanggan dan mengukur kesuksesan berasarkan kesuksesan pelanggan. Kesuksesan kita ditentukan oleh pemahaman kita perihal apa yang dapat kita lakukan untuk menciptakan nilai bagi pelanggan. Bila kita tak dapat mempengaruhi kinerja pelanggan secara positif, produk kita akan menjadi produk komoditas dan kita mendapatkan harga komoditas.

Pengurangan biaya adalah ukuran yang rasional dan dipakai sebagian besar tenaga penjual ketika mengajukan penawaran pada bagian pembelian sebuah perusahaan. Bila hanya ini yang kita lakukan, kita mengabaikan banyak nilai. Setiap bisnis mempunyai kombinasi ukuran yang dipakai untuk mengukur apakah perusahaan menciptakan nilai bagi pemegang saham. Bahkan orang yang tak pernah mengikuti pelatihan finansial pun dapat belajar memahaminya. Penjualan penciptaan nilai adalah yang berorientasi pada pelanggan. Artinya, segala sesuatu yang dilakukan perusahaan berpusat pada pelanggan. Sayangnya, hal itu tidak selalu terjadi. informasi terperinci yang berlimpah, baik fakta maupun kesan, adalah jantung dari penjualan penciptaan nilai. Konsepnya sederhana, semakin banyak kita mengetahui tentang pelanggan, semakin mahir kita dan perusahaan mengidentifikasi persoalan pelanggan serta membuat produk dan layanan yang akan membantu menangani persoalan tersebut. Dalam pengertian yang paling luas, kita ingin mempelajari peluang pelanggan dan dinamika kompetitif yang dihadapi perusahaan pelanggan. Kuncinya adalah menganalisa pertumbuhan dan positioning pasar pelanggan.

Kita dapat melihat bahwa bukan hanya kuantitas informasi mengenai perusahaan yang penting, tetapi juga kualitasnya. Mengetahui bagan organisasi pelanggan kita adalah bagian dari kuantitas. Mengetahui siapa yang sesungguhnya membuat keputusan adalah informasi berkualitas. Informasi berkualitas adalah hal yang menentukan seberapa jauh kita memahami pelanggan dan apakah kita mampu mengembangkan serta menjual usulan nilai yang berkenaan dengan peluang dan 
tantangan pelanggan. Untuk menjadi mitra kepercayaan pelanggan, kita harus memahami hal-hal berikut: (1) kumpulan peluang pelanggan dan anatomi dinamika kompetisi; (2) pelanggan dari pelanggan dan pesaing pelanggan; (3) cara pembuatan keputusan pada organisasi pelanggan; (4) budaya korporat, psikologi, dan nilai dominan yang berlaku pada perusahaan pelanggan; dan (5) sasaran dan prioritas pelanggan, baik jangka pendek maupun jangka panjang, secara jelas dan spesifik.

Dalam penjualan penciptaan nilai, ketajaman bisnis adalah keharusan. Ketajaman ini adalah untuk menciptakan usulan nilai yang menjangkau kebutuhan pelanggan yang lebih luas dan berarti. Kepuasan pelanggan adalah bagian besar dari persamaan pangsa pasar. Seorang pelanggan yang puas akan menceritakan kehandalan produk yang mereka beli kepada orang lain, dan mereka akan kembali untuk membeli. Ketika mobil buatan Jepang seperti Toyota untuk pertama kalinya diimpor ke AS pada tahun 1960-an, produk ini tidak terlalu menarik bagi kebanyakan konsumen AS karena ukurannya yang kecil, tenaganya yang tidak terlalu besar, dan bentuknya yang tidak terlalu bagus. Namun, sebagaimana kita ketahui, pihak Jepang mempelajari pasar AS secara cermat, mengatasi masalah yang ada, dan tak lama kemudian mulai menawarkan produk berkualitas tinggi dengan harga yang lebih rendah daripada mobil buatan Detroit. Kini Toyota dan Honda secara konsisten menduduki peringkat atas diantara para pembuat mobil dunia dalam hal kepuasan pelanggan, terutama menyangkut keandalan dan kualitas. Mereka berada dalam posisi menguntungkan untuk memperluas pangsa dalam pasar yang senantiasa berkembang. Pelanggan kita ingin membuat pelanggan mereka bahagia, puas dengan harga dan kinerja produk mereka. Tugas kita adalah membantu mereka mencapai tujuan ini. (Charan, 2007)

Hal yang biasanya tidak disukai seorang tenaga penjual adalah pekerjaan administrasi. Namun, ada sebuah dokumen yang harus dimiliki setiap perusahaan: Value Account Plan (rancangan catatan nilai), atau VAP. Value Account Plan adalah dokumen yang mendefinisikan usulan nilai dan manfaat bisnis yang diperoleh pelanggan. Manfaat tersebut harus dinyatakan dalam ukuran bisnis, dalam ukuran kuantitatif seperti pengurangan harga, pertumbuhan pendapatan, dan perbaikan aliran kas, serta ukuran kualitatif seperti besar pangsa pasar dan citra merek. Menerjemahkan kebutuhan pelanggan menjadi penawaran unik dengan manfaat bisnis yang jelas merupakan perbedaan pokok antara penjualan penciptaan nilai dan pendekatan penjualan tradisional. VAP menyediakan panduan penerjemahan tersebut dan merupakan alat utama dari pendekatan baru terhadap penjualan ini.

Value Account Plan (VAP) adalah sebuah template pada sebuah komputer atau secarik kertas, yang harus diisi seorang tenaga penjual dengan bantuan rekan di bagian lain perusahaan. Namun, dokumen ini tak dapat diisi secara mekanis karena kualitas wawasanlah yang diutamakan. VAP menuntut pemikiran yang kuat. Proses ini memaksa tim bekerja melampaui apa yang sudah mereka ketahui dan apa yang disampaikan pelanggan untuk mendefinisikan penawaran yang memberikan manfaat bisnis yang mungkin tidak disadari kebutuhannya oleh pelanggan. Hal itu mendorong tim untuk bekerja sama menggunakan informasi lengkap yang mereka kumpulkan tentang pelanggan, lalu memikirkan bisnis pelanggan secara lebih luas dan menciptakan usulan nilai yang membantu perkembangan bisnis tersebut. Pekerjaan mental yang diperlukan untuk menciptakan VAP menjadikan pengumpulan informasi ini modal intelektual berharga.

Seorang tenaga penjual memimpin dalam mendorong terbentuknya sebuah tim multidisiplin untuk menganalisis informasi pelanggan dan membuat VAP. Begitu sudah rampung, VAP menjadi acuan perusahaan dalam bekerja sama. VAP adalah dokumen bersama yang dapat diakses orang yang tepat dalam perusahaan kita dan karenanya memberi fokus serta kesinambungan, meskipun anggota kunci tim penjualan pergi atau dipromosikan. Beberapa tenaga penjual mungkin merasa VAP menjadikan mereka kurang penting, tetapi nyatanya dengan tugas baru mereka dalam mengawasi, mengisi, dan menggunakan VAP untuk membentuk usulan nilai yang menarik bagi pelanggan, peran mereka justru meningkat. Meskipun awalnya menentang, mereka akhirnya akan menganggap VAP sebagai alat paling bermanfaat yang mereka miliki. 
Kita tidak akan dapat memesan perangkat lunak jadi untuk VAP kita. Perusahaan yang melaksanakan penjualan penciptaan nilai telah menciptakan versi mereka sendiri yang disesuaikan dengan kebutuhan pelanggan, organisasi, dan industri mereka. Beberapa perusahaan membuat sendiri aplikasi perangkat lunak mereka, sementara yang lain menggunakan format cetak. Kita harus menciptakan VAP kita sendiri. Hal ini tidak sulit begitu kita memahami hal pokok tentang apa yang harus dimuat dalam VAP dan cara menggunakannya. Setiap VAP harus mencakup tiga unsur, yaitu deskripsi singkat atau potret pelanggan, usulan nilai, dan manfaat yang diberikan usulan nilai kepada pelanggan yang dinyatakan dalam istilah fisik, seperti "memperbaiki waktu silus X menit" atau " mengurangi stok sebanyak $\mathrm{X}$ dollar”, dan pada istilah bisnis, seperti biaya, pendapatan, margin laba, uang tunai, ROI, pangsa pasar, dan brand equity.

\section{Potret Pelanggan}

Tiga komponen utama VAP yang pertama adalah deskripsi singkat tentang pelanggan. Dalam mempersiapkan VAP, kita harus mengumpulkan banyak informasi tentang pelanggan. Inilah bahan mentah yang diperlukan untuk membuat VAP. Kita harus memulai dengan mencatat hal pokok, yaitu nama perusahaan, bidang bisnis, informasi lokasi kantor pusat dan cabang perusahaan, serta nama para eksekutif senior. Selanjutnya, seorang tenaga penjual memimpin dengan mengarahkan bantuan rekanrekanya utuk menyaring fakta penting guna membuat gambaran jelas dan singkat tentang bisnis total pelanggan. Kita harus memperluas jangkauan untuk melihat gambaran besar bisnis pelanggan, gambaran finansial, dinamika persaingan, sasaran, pasar, operasional, dan seluruh rantai nilainya. Kita tak dapat menilai sesuatu secara kasat mata, tetapi kita harus berpikir secara kreatif untuk memahami realitas bisnis pelanggan, meringkasnya ke hal-hal pokok. Inilah waktunya memikirkan kesan dan persepsi serta membuat beberapa pertimbangan.

Seandainya kita mempunyai data finansial pelanggan untuk lima tahun terakhir, eksekutif finansial kita dapat menganalisisnya untuk mencari perubahan penting. Mereka mungkin dapat melihat bahwa margin seorang pelanggan yang terus merosot, serta struktur utangnya yang tinggi dalam kondisi ekonomi dengan tingkat suku bunga yang meningkat dan uang ketat, tengah menghadapi keadaan keterbatasan uang tunai. Pelanggan boleh saja menegaskan perusahaannya akan tumbuh dengan cepat, tetapi kita mungkin menyimpulkan hal sebaliknya. Pelanggan lain mungkin mengalami peningkatan kekuatan finansial dan mengumpukan banyak uang. Kita dapat menggabungkan data ini dengan informasi lain, mungkin dengan mencatat bahwa segmen pasar yang digeluti pelanggan tersebut sedang tumbuh dan bahwa para pesaingnya mengalami masa sulit. Semua itu harus dicatat dalam bahasa yang singkat dan digunakan untuk membentuk usulan nilai. Kita mungkin mengetahui sasaran jangka pendek dan jangka panjang pelanggan. Sasaran jangka pendek cenderung realistis. Bila tidak, biasanya sasaran ini dapat disesuaikan dengan cukup cepat. Namun, sasaran jangka panjang pelangan mungkin seperti mimpi di siang bolong, yang hanya disesuaikan sedikit selama beberapa waktu sampai akhirnya menjadi jelas bahwa sasaran tersebut tak dapat dicapai. Inilah saatnya perusahaan kemungkinan mengambil langkah mendadak, yaitu mengubah sasaran dan arah strategis mereka secara radikal. Bila melacak betapa mulus atau susahnya pelanggan bergerak menggapai sasaran, kita mungkin dapat memprediksi kemungkinan membuat perubahan radikal.

Potret pelanggan juga harus mencakup informasi tentang para pembuat keputusan di pihak pelanggan. Keputusan jarang dibuat hanya dalam sekali pertemuan atau oleh satu orang. Kita perlu mencari tahu siapa yang membuat keputusan, apa atau siapa yang memengaruhi keputusan, dan bagaimana mereka membuat keputusan tersebut. Anggaran siapa, di perusahaan pelanggan, yang akan dipakai ? bagaimana perubahannya ? apakah jelas, atau apakah kita harus mencari beberapa petunjuk tambahan ? Kita dapat melihat potret ini sebagai seperangkat butir urut atau paragraf, yang mana yang terbaik untuk kita, sambil mengingat bahwa bisnis selalu mengalir. Kita harus memperbaharui ini dengan memperhatikan perubahan yang terjadi pada orang, hubungan, dan struktur organisasi pada level pembelian serta dalam organisasi. 


\section{Usulan Nilai}

Bagian kedua dari VAP adalah usulan nilai. Disini, kita mendefinisikan kebutuhan pelanggan yang akan kita penuhi, mendefinisikan perpaduan penawaran yang disesuaikan dengan kebutuhan pelanggan, harganya, dan implikasinya terhadap pendapatan, biaya, uang, investasi modal, serta profitabilitas perusahaan kita. Menciptakan usulan nilai mungkin tampak seperti hal biasa. Bedanya, di sini VAP memaksa kita bepikir tentang bisnis pelanggan secara menyeluruh, dan memanfaatkan pemikiran terbaik orang dan berbagai bagian di perusahaan kita, untuk mendapatkan usulan nilai yang memberikan manfaat kepada pelanggan melampaui penghematan biaya yang biasa.

Salah satu rintangan terbesar bagi tenaga penjual yang baru mengenal penjualan penciptaan nilai adalah cara menjangkau orang selain orang yang biasa mereka temui di bagian pembelian dan langsung mendapatkan perhatian mereka. Tidak ada rumus untuk melakukannya, tetapi perusahaan yang melakukan pendekatan penjualan seperti ini mengembangkan metode untuk membangun koneksi, jaringan, dan mendapatkan informasi yang mereka perlukan. Hal itu sering berupa persoalan menghubungi orang di perusahaan kita yang mungkin mempunyai hubungan pertemanan atau hubungan kerja dengan seseorang di perusahaan pelanggan dan bersikap agresif dalam menjalin hubungan dengan orang tersebut. Kita hidup dalam masyarakat yang suka bergaul, jadi ada kemungkinan seseorang di perusahaan kita mengenal seseorang di perusahaan pelanggan. Kita memperbesar peluang bila membangun jejaring dengan orang-orang dari berbagai fungsi dan tingkat di perusahaan kita. Selain itu, seorang tenaga penjual dapat bertanya kepada rekannya di perusahaan pelanggan siapa yang harus ditemui rekan satu perusahaannya. Saat para tenaga penjual dan rekan mereka menemukan cara untuk berdialog dengan pelanggan, mereka dapat menggunakan koneksi mereka untuk membuat usulan nilai yang menyentuh kebutuhan serta prioritas di luar departemen pembelian.

Seandainya pelanggan adalah sebuah perusahaan barang konsumsi yang menggunakan jasa pengemasan kita. Bagian pembelian perusahaan terutama tertarik pada harga atau biaya pengemasan dan kehandalan pengiriman serta kualitas. Namun, bagian pemasaran di perusahaan yang sama tertarik pada bagaimana pengemasan berdampak pada penggunaan ruang rak di toko peritel dan apakah pengemasannya akan memperkuat merek. Seorang pemimpin senior atau eksekutif humas perusahaan akan peduli dengan daya tahan dan apakah produknya "ramah lingkungan". Mengetahui ini semua, kita mungkin akan membuat usulan nilai untuk menyediakan kemasan yang dapat di daur ulang, selaras dengan merek dalam segi estetika dan kualitas, menggunakan rang rak secara efisien, serta dapat dibeli dengan harga terjangkau. Usulan nilai seperti ini akan memikat banyak orang di perusahaan pelanggan, termasuk para eksekutif tingkat tinggi, yang mngkin akan mempertimbangkan keputusan untuk membeli. Hal itu akan memberikan nilai yang lebih besar pada bisnis pelanggan.

Dalam merumuskan solusi yang sukses bagi seorang pelanggan, dibutuhkan lebih dari satu silo. Orang harus berbagi dan berdebat, terutama secara horizontal, tentang apa yang tersedia atau yang memungkinkan, lalu berkomitmen. Bila hanya menggabungkan beberapa produk yang sudah ada, kita mungkin tidak akan menghasilkan solusi penciptaan nilai yang sesungguhnya. Sebaliknya, bila kita sekedar menggabungkan produk, pelanggan akan bisa memisahkan komponennya dan meminta harga secara terpisah, lalu meminta diskon. Hal itu berarti kita mengalami kemunduran. Agar usulan nilai menjadi unik, pemimpin tim penjualan harus menuntut tim nya memikirkan cara memadukan kemasan sesuai kebutuhan pelanggan, suatu hal yang akan menciptakan nilai dan memberi solusi yang berbeda daripada yang ditawarkan pesaing. Hal ini akan membuat penciptaan nilai melebihi jumlah bagiannya. Kita juga harus memikikan harga dan informasi biaya sejak awal agar keuntungan pelanggan menjadi nyata dan memastikan rencana ini akan menghasilkan uang untuk perusahaan. Harga harus disesuaikan untuk setiap pelanggan dan untuk setiap solusi dengan menggunakan keahlian terbaik di perusahaan kita. Dalam menetapkan harga, banyak perusahaan mengabaikan kepentingan tenaga penjual. Bila solusinya benar, kita dapat menetapkan harga premium dan mengabaikan penetapan harga "biaya plus" 
Sebuah perusahaan yang menjual solusi penciptaan nilai menggunakan penetapan harga nilai yang merupakan suatu hal yang berbeda. Menetapkan harga nilai berarti kita harus menghitung nilai total dari apa yang kita tawarkan kepada pelanggan. Lalu, kita harus memperkirakan, dengan menggunakan pengetahuan terbaik kita, apa yang akan ditawarkan pesaing. Apakah mereka mempunyai kemampuan mengajukan solusi cerdas dan bagaimana mereka akan menetapkan harganya? bagaimana pelanggan memandang solusi yang kita usulkan dan seberapa baik pelanggan memahami nilai dari solusi kita? Bila kita tidak mengubah proses persetujuan untuk menetapkan harga usulan nilai kita, penjualan penciptaan nilai tak akan berhasil. Penerapan harga nilai menunjukkan kepada pelanggan bahwa kue akan bertambah untuk perusahaannya dan perusahaan kita, dan kelak persoalannya adalah menentukan pembagian kue. Dalam penjualan transaksi, seorang tenaga penjual merasa bertanggung jawab atas kinerja produk. Dalam membentuk VAP, pemimpin penjualan merasa bertanggungjawab atas hasil bisnis yang dicapai pelanggan

Para tenaga penjual mungkin memiliki kendala psikologis menyangkut penetapan harga premium. Mereka terbiasa menghadapi pelanggan yang gigih menawar harga, dan sering kehilangan kesempatan menjual. Saat merasa lebih terbiasa membentuk usulan nilai yang memenuhi berbagai kebutuhan bisnis mereka akan menyadari bahwa penetapan harga premium adalah suatu hal yang dibenarkan, dan bahwa pelanggan bersedia menerimanya. Bagian keuangan mungkin akan menolak konsep penetapan harga nilai karena konsep ini membutuhkan lebih banyak pertimbangan daripada penetapan harga biaya plus, tetapi dengan betambah mahirnya orang-orang kita dalam mendefinisikan keuntungan bisnis yang diperoleh, selain penghematan biaya, semua ini menjadi masuk akal.

\section{Manfaat Bisnis}

Bagian ketiga VAP mendefinisikan manfaat dari usulan nilai. Di sebagian besar perusahaan, agen penjualan terbiasa memandang nilai sebagai total cost of ownership (biaya total kepemilikan pelanggan), atau TCO, yang mencakup biaya pembelian dan setiap pengeluaran terkait penggunaannya, lalu membandingkannya dengan potensi penghematannya. Namun, bagian ketiga dari VAP ini dibuat untuk menentukan total value of ownership (nilai total kepemilikan), atau TVO. Total Value of Ownership adalah estimasi semua manfaat yang akan diperoleh pelanggan serta kemungkinan kerugian yang akan mereka alami bila memilih cara lain. Dalam industri di mana inovasi sering terjadi, pelanggan yang memutuskan melakukan pembelian berdasarkan harga, dan bukan nilai total, akan sulit bersaing dan tetinggal.

Pertama-tama kita harus menegaskan manfaat fisik usulan nilai kita, kurangi kesalahan penagihan hingga setengah, misalnya, atau kurangi pemakaian bahan mentah sebesar $20 \%$. Lalu jabarkan dan hitung semua manfaat bisnis dari solusi ini. Beberapa manfaat bisnis bersifat kuantitatif, misalnya penghematan biaya atau peningkatan pendapatan yang diproyeksikan, margin atau aliran kas, dan pangsa pasar. Manfaat lainnya bersifat kualitatif, seperti kelanggengan hubungan dengan pelanggan dan citra merek yang bertambah baik. Kita harus berpikir dengan mengacu pada manfaat usulan nilai kita dan merasa nyaman menilai usulan tersebut, sambil mengingat bahwa manfaat seperti pertumbuhan pendapatan serta peningkatan merek adalah nilai yang berharga bagi pelanggan.

Misalnya seorang pemasok perangkat lunak dapat menambah jumlah telepon penjualan tenaga penjual sebuah perusahaan farmasi ke dokter. Menambah jumlah telepon penjualan dari 10 ke 15 per orang per minggu adalah manfaat fisik, inilah yang dilakukan solusi tersebut. Namun, bila setiap lima telepon penjualan tambahan tersebut menghasilkan pendapatan rata-rata Rp 50 juta, manfaat fisik ini akan menghasilkan pendapatan tambahan sebesar Rp 25 juta per tenaga penjual per minggu. Bila jumlah Rp 25 juta ini dikalikan dengan 52 minggu. Kita mendapatkan angka Rp 13,3 milyar. Lalu, kalikan jumlah Rp 13,3 milyar tersebut dengan seribu tenaga penjual dan kita mendapati bahwa pelanggan akan menghasilkan pendapatan tambahan tahunan sebesar Rp 13,3 triliun bila menggunakan perangkat lunak tersebut. Angka ini pasti menarik bagi manajemen puncak. Ini adalah 
manfaat spesifik bagi bisnis pelanggan yang dapat dihitung dan diukur setelah beberapa waktu. Perangkat lunak tersebut mungkin dapat juga memberi manfaat kualitatf, seperti meningkatnya kepuasan pelanggan dan bertambah baiknya citra merek. Hal itu semua akan dicatat dalam VAP dan dimasukkan ke TVO pelanggan.

Walaupun agen penjualan dapat meminta bantuan rekan mereka untuk menerjemahkan manfaat fisik kedalam bahasa keuangan, mereka harus mengasah ketajaman bisnis. Berpikir dari sisi bagaimana manfaat fisik dapat memperbaiki kinerja bisnis pelanggan merupakan inti tugas mereka dalam Penjualan Penciptaan Nilai. Mereka juga diharapkan memahami dasar-dasar laporan pendapatan dan neraca. Perlu diingat bahwa bila disederhanakan secara mendasar, bisnis adalah sesuatu yang masuk akal. Bisnis dapat dipelajari melalui praktek, dengan dipandu pemimpin yang ketajaman bisnisnya sudah terasah. Kenyataannya, beberapa orang tenaga penjual mempelajarinya sehingga kita tahu hal ini dapat dilakukan. Mereka yang berlatih menggunakan ketajaman bisnis dalam membuat VAP sungguh akan menjadi lebih mahir. Akhirnya, mereka akan melakukan lebih banyak penjualan berdasarkan fakta, kuantifikasi, pertimbangan bisnis yang matang, dan definisi mereka tentang kebutuhan pelanggan daripada sekadar berdasarkan persuasi atau hubungan pribadi.

Yang perlu kita perhatikan adalah bahwa bila manfaat yang kita tawarkan meliputi banyak bidang bisnis pelanggan, mungkin pelanggan akan menetapkan anggaran yang lebih besar. Solusi pengemasan yang inovatif mungkin sebagian berasal dari anggaran pengemasan pelanggan dan sebagain lagi mungkin dari anggaran pemasaran yang melihat adanya keuntungan saat melakukan pembelian.

Dalam VCS, menjual produk hanyalah sebuah awal. Bukti keberhasilan produk yang kita jual adalah ketika pelanggan mengakui manfaat yang kita janjikan. Manajemen puncak harus menciptakan alat untuk mengukur kesuksesan bagi setiap order dan mendapatkan persetujuan pelanggan. Tim harus diberi imbalan setiap kali pelanggan mengakui manfaat yang diusulkan. Melaksanakan strategi Penjualan Penciptaan Nilai adalah komitmen jangka panjang. Perusahaan yang berhasil menjalankannya membutuhkan waktu sekitar tiga tahun untuk menjadi mahir, dan kebanyakan dari mereka terus memperbaiki prosesnya. Kesuksesan menuntut diulangnya secara terus-menerus prinsip bahwa perusahaan akan maju hanya jika pelanggan maju, sebuah pesan yang lebih mudah disampaikan bila kita mulai memetik keberhasilan (Charan, 2007).

\section{METODE PENELITIAN}

Metode penelitian yang digunakan adalah metode studi kasus, yaitu berdasarkan kasus yang terjadi pada PT XYZ, suatu grup perusahaan yang bergerak dalam bidang freight forwarding/logistics service provider atau Third-Party Logistics Services (3PLs), dimana kantor pusatnya berlokasi di Jakarta dan mempunyai banyak kantor cabang di berbagai daerah. Adapun kasus yang diambil adalah Proyek Loon-Brunei - PT ABC. Data yang digunakan adalah data primer dan data sekunder. Data primer adalah data yang diperoleh dari interview sedangkan data sekunder diperoleh melalui studi literatur dan internet.

Adapun yang dimaksud dengan Third Party Logistics adalah pihak yang ditunjuk oleh pemilik barang untuk menyediakan jasa transportasi dan servis lainnya termasuk pergudangan, persiapan dokumen, kepabeanan, pengepakan, labeling, dan sebagainya (Wisner, 2012). Logistics Service Provider pada umumnya menjalankan usaha mencakup kegiatan-kegiatan supply chain management, delivery and customs clearance, distribution management, dan import logistics dan outbound distribution (Branch, 2009). 


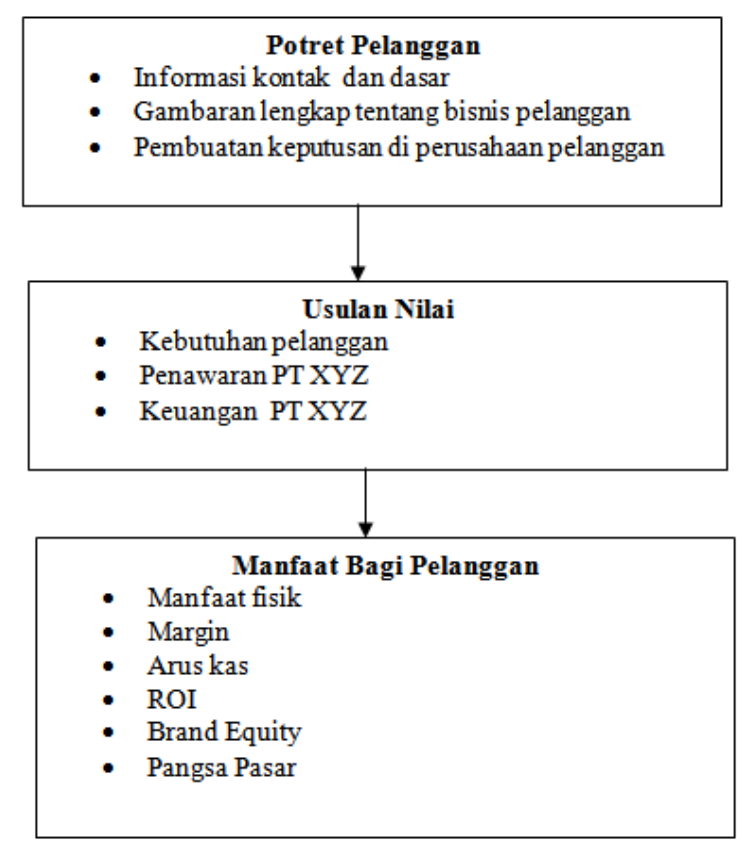

Gambar 1 Kerangka pikir

\section{HASIL DAN PEMBAHASAN}

\section{Potret Pelanggan:}

\author{
Nama Perusahaan \\ Bidang Bisnis \\ Alamat \\ Nama PIC
}

\author{
: PT ABC \\ : Geoscience, Drilling, Oilfield \\ : JL TB Simatupang, Jakarta Selatan \\ : Senior Procurement Manager
}

PT ABC adalah perusahaan cukup besar dan sudah go public (terbuka), pemilik saham perusahaan ini adalah PT Pertamina dan Perusahaan Asing. Kondisi keuangan cukup baik dengan current ratio 108\%, margin laba bersih 5\%, dan modal kerja sebesar 76 milyar rupiah. Perusahaan ini memiliki proyek geosciences di Brunei, sehingga memerlukan pengiriman barang-barang berupa geophysical equipment untuk menggarap proyek tersebut kemudian sebagian besar barang-barang tersebut akan dikirim kembali ke Jakarta setelah selesai digunakan, pengiriman akan dilakukan dengan moda laut dan udara. Untuk pekerjaan pengiriman barang-barang tersebut dilakukan secara tender terbuka, sehingga harga yang murah menjadi sasaran utama. Tender diikuti oleh 9 peserta dengan penentu keputusan adalah Senior Procurement Manager. Selain itu, proyek ini merupakan proyek pertama PT ABC di luar negeri, sehingga sangat menjadi perhatian Direksi. Proses penciptaan nilai dari kegiatan ini adalah, pengadaan barang, proses pengiriman, operasional, dan pengiriman kembali.

\section{Usulan Nilai}

Kebutuhan PT ABC terhadap pelayanan PT XYZ adalah: (1) pengiriman geophysical equipment melalui moda laut dan udara; (2) jenis pengiriman adalah ekspor sementara (re-import); (3) cakupan kegiatan meliputi stuffing di gudang dengan manual/buruh dan mekanik, stuffing kedalam kontainer (laut) atau muat ke atas truk (udara), clearance ekspor, freight laut atau udara, port dan shipping charges di Jakarta dan Brunei, import clearance di Brunei, delivery ke Project Site, 
unstuffing di Project Site, asuransi barang selama pengiriman; (4) proses pekerjaan sesuai standar ISO dan HSE; (5) pengurusan SKEP ekspor sementara; (6) terms of payment, 30 hari dari penerimaan invoice; (7) waktu pengiriman: lewat laut 10 hari, lewat udara 3 hari; (8) pengiriman dilakukan secara bertahap selama kurang lebih satu tahun; (9) nilai keseluruhan untuk pengiriman barang-barang ini sekitar Rp 3 milyar.

Setelah dilakukan perhitungan, maka diputuskan untuk penawaran rate (quotation) sesuai cakupan pekerjaan di atas dengan profit margin sekitar 30\%, adalah:

Lewat Laut : : Rp 23.625.000 per kontainer 20'

Lewat udara $\quad$ : Rp 55.000 per kg

Untuk menggarap pekerjaan ini, PT XYZ membutuhkan dana untuk pre-finance minimal sebesar Rp 500 juta. Adapun kondisi keuangan PT XYZ sendiri cukup baik, dengan current ratio 215\%, net margin ratio 5\%, dan modal kerja kurang lebih sebesar 50 milyar.

\section{Manfaat Bagi Pelanggan (Total Value of Ownership)}

PT ABC cukup mengeluarkan instruksi pengiriman kepada PT XYZ dilengkapi dengan dokumen-dokumen pendukung, selanjutnya tinggal monitor proses pengiriman, sehingga PT XYZ dapat lebih fokus kepada pekerjaan intinya. Selain itu, proses pengiriman dan pengurusan dokumentasi yang relatif cepat, harga pengiriman yang lebih murah, dan kualitas pelayanan yang lebih baik. Secara keseluruhan PT ABC dapat mengehemat biaya sekitar 20\%. Profit margin PT ABC lebih besar karena biaya pengiriman lebih efisien karena mendapatkan Vendor dengan biaya termurah melalui tender, tidak ada resiko kehilangan dan kerusakan barang, karena ditanggung oleh asuransi dan perusahaan forwarder. Arus kas naik, karena pembayaran kepada Vendor selama 30 hari dari tanggal penerimaan invoice, sehingga membantu dalam arus kas proyek.

ROI PT ABC akan naik karena net profit dari proyek tersebut meningkat karena adanya efisiensi, kemudian tidak perlu investasi sarana atau fasilitas fisik logistik karena menggunakan sarana atau fasilitas pihak ketiga (Third Party Logistics / 3PLs). Citra merek PT ABC di luar negeri akan naik, karena apabila proyek tersebut sukses dengan proses pengadaan dan pengiriman peralatan/perlengkapan berjalan secara lancar dan tepat waktu, maka PT ABC akan mempunyai pegalaman proyek di luar negeri yang cukup besar dan menjadi pertimbangan pemilihan bagi calaon pelanggannya. Pangsa pasar PT ABC akan naik, karena pelaksanaan proyek yang sukses akan menumbuhkan permintaan baru terhadap proyek lainnya minimal di negara yang bersangkutan. Selain itu, akan memicu juga permintaan untuk proyek yang sama dari negara-negara lain.

\section{SIMPULAN}

Sebuah perusahaan yang menjual solusi penciptaan nilai menggunakan penetapan harga nilai, yang merupakan suatu hal yang berbeda. Menetapkan harga nilai berarti kita harus menghitung nilai total dari apa yang kita tawarkan kepada pelanggan. Lalu, kita harus memperkirakan, dengan menggunakan pengetahuan terbaik kita, apa yang akan ditawarkan pesaing. Apakah mereka mempunyai kemampuan mengajukan solusi cerdas dan bagaimana mereka akan menetapkan harganya? bagaimana pelanggan memandang solusi yang kita usulkan dan seberapa baik pelanggan memahami nilai dari solusi kita? Bila kita tidak mengubah proses persetujuan untuk menetapkan harga usulan nilai kita, penjualan penciptaan nilai tak akan berhasil. Berdasarkan analisis terhadap potret pelanggan, usulan nilai, dan manfaat bagi pelanggan (total value of ownership), maka secara keseluruhan nilai efisiensi yang diberikan adalah sekitar 20\% dibanding pesaing terdekat, pengiriman barang yang aman dan tepat waktu, serta manfaat yang positif terhadap profit margin, cash flow, return on investment, brand equity, dan market share pelanggan. 


\section{DAFTAR PUSTAKA}

Branch, A. E. (2009). Global supply chain management and international logistics, $1^{\text {st }}$ ed. New York: Routledge.

Charan, R. (2008). What the customer wants you to know. Jakarta: Gramedia Pustaka Utama.

Fisk, P. (2006). Marketing genius. England: Capstone.

Johnston, M. W., \& Marshall, G. W. (2009). Relationship selling. New York: McGraw-Hill.

Kotler, P., \& Amstrong, G. (2010). Principles of marketing. New Jersey: Pearson Education.

Manning, G. L., \& Reece, B. L. (2007). Selling today: Creating customer value. New Jersey: Pearson Education.

Wisner, J. D., Tan, K. C. T., Leong, G. K. (2012). Principles of supply chain management: A balanced approach. New York: South-Western. 